\title{
Simple atrophic gastritis and gastric carcinoma
}

\author{
I. R. WALKER, ${ }^{1}$ R. G. STRICKLAND, B. UNGAR, AND I. R. MACKAY \\ From the Clinical Research Unit, the Walter and Eliza Hall Institute of Medical Research and Royal Melbourne \\ Hospital, Melbourne, Australia
}

SUMMARY Gastric carcinoma was detected nine, 10, 18, and 21 years after the biopsy diagnosis of atrophic gastritis in four patients of a group of 40 . The gastritis was presumed to be of the simple type. Tests of vitamin $\mathbf{B}_{12}$ absorption in three patients gave normal results, no gastric autoantibodies were detected in the two patients tested, in all patients histological examination of the gastrectomy specimens revealed a multifocal gastritis differing from the diffuse gastritis of pernicious anaemia and in three patients the gastritis affected the antrum, which is unusual in pernicious anaemia.

The $10 \%$ incidence of gastric carcinoma in 40 patients with simple atrophic gastritis followed for a mean period of 15 years is equivalent to that previously described in pernicious anaemia. However, in view of the relative incidence of atrophic gastritis with and without pernicious anaemia in the general adult population, it emerges that atrophic gastritis without pernicious anaemia is numerically the more important precursor of gastric carcinoma.

In patients with Addisonian pernicious anaemia, in whom atrophic gastritis is invariably present, there is said to be an increased incidence of gastric carcinoma (Magnus, 1958). Moreover, gastritis with intestinal metaplasia was described in the mucosa around a gastric carcinoma or in areas remote from the tumour site in 36 of 39 stomachs removed surgically (Morson, 1955a and b), but it is uncertain whether the gastritis accompanying gastric malignancies represents an antecedent premalignant state or is a secondary consequential reaction to the tumour. The four case reports described here document the supervention of gastric cancer on an antecedent gastritis of long standing, and in all cases this gastritis was not of the 'autoimmune' type associated with pernicious anaemia.

\section{Material and Methods}

\section{PATIENTS}

The present four case reports were derived from long-term observations of $\mathbf{4 0}$ patients with atrophic gastritis, many of whom have been the subjects of previous studies from this Unit (Fairley, Turner, Mackay, and Joske, 1955; Wood, Ralston, Ungar, and Cowling, 1964). The period of observation of

\footnotetext{
${ }^{1}$ Present address: Department of Medicine, McMaster University, Hamilton, Ontario, Canada

Received for publication 12 August 1971.
}

this group of patients ranges from nine to 22 years (mean 15 years).

\section{PROCEDURES}

Gastric biopsies were performed with the Wood tube (Wood, Doig, Motteram, and Hughes, 1949). Gastric acid secretion was assessed over one hour by the response to submaximal (Weiden, 1949) or maximal (Kay, 1953) doses of histamine acid phosphate.

\section{LABORATORY ANALYSES}

Gastric acidity was measured before 1965 by titration of the gastric aspirate with 0.01 sodium hydroxide using Topfers reagent and phenolphthalein as indicators, and thereafter electrometrically. Serum vitamin $B_{12}$ levels were measured before 1965 by the method of Ross (1952) using Euglena gracilis $\mathbf{Z}$ strain and the medium of Hutner, Bach, and Ross (1956), and thereafter by the method of Anderson (1964). The normal range is $200-800 \mathrm{pg} / \mathrm{ml}$. Vitamin $B_{12}$ absorption was measured by the urinary excretion test of Schilling (1953) as described by Ungar, Stocks, Martin, Whittingham, and Mackay (1968); the lower normal limit is taken to be $10 \%$ excretion of the administered dose. In a few instances absorption of vitamin $\mathbf{B}_{\mathbf{1 2}}$ was measured by the faecal excretion method of Heinle, Welch, Scharf, Meacham, and Prusoff (1952) as described 
by Wood, Cowling, Ungar, and Gray (1960). Antibody to gastric intrinsic factor was detected by a modification (Ungar, 1967) of the coated charcoal method (Gottlieb, Lau, Wasserman, and Herbert, 1965), and antibody to gastric parietal cells by indirect immunofluorescence using rat stomach as source of antigen (Whittingham and Mackay, 1969).

\section{Case Reports}

\section{PATIENT 1}

G.T., a 54-year-old man, presented in 1947 with intermittent indigestion for six months. Examination was unremarkable, a barium meal $x$-ray examination was normal; there was achlorhydria. Between 1951 and 1961, four gastric biopsies were performed; each showed chronic atrophic gastritis with intestinal metaplasia and achlorhydria was demonstrated repeatedly. In 1960 , vitamin $B_{12}$ absorption was normal and several serum vitamin $\mathbf{B}_{12}$ estimations gave normal results. In 1961 abdominal pain recurred and a barium meal $x$-ray examination revealed a filling defect on the greater curvature of the body of the stomach. At operation an ulcerating carcinoma was found (Fig. 1). A partial gastrectomy was performed but death occurred after several days from pneumonia. At necropsy there was no evidence of metastases.

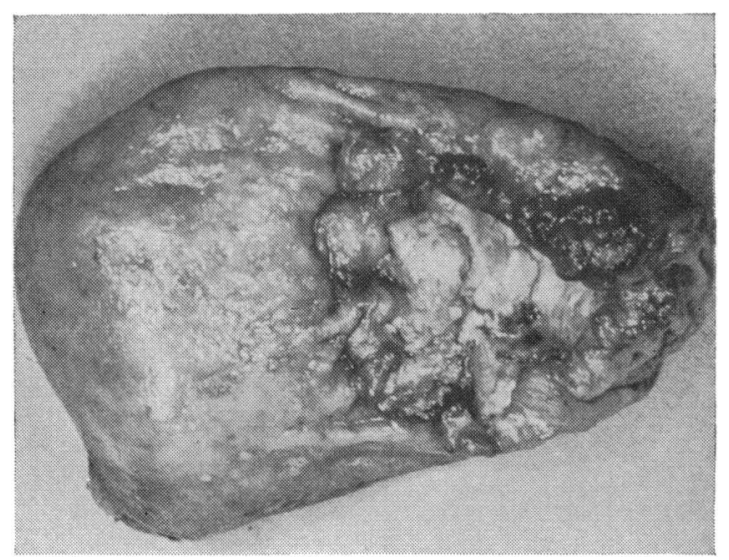

Fig. 1 Gastrectomy specimen from patient G.T. Ulcerating carcinoma in the body of stomach and surrounding atrophic mucosa.

\section{PATIENT 2}

L.M., a 64-year-old woman, presented in 1946 with 20 years of indigestion not relieved by alkali; examination was unremarkable. A barium meal $x$-ray examination was normal. There was achlorhydria. In 1951 gastroscopy showed features of atrophic gastritis, and gastric biopsies in 1951 and on three further occasions over the following nine years all showed chronic atrophic gastritis. Achlorhydria was demonstrated repeatedly. In 1959-60, serum vitamin $B_{12}$ levels were normal on several occasions. In 1960, unexplained weight loss led to a barium meal $x$-ray examination which showed rigidity and narrowing of the body of the stomach. A total gastrectomy was performed but the patient died after two weeks from intraperitoneal sepsis. The resected stomach contained a non-ulcerated infiltrating carcinoma involving the body and proximal antrum. At necropsy there was no evidence of metastases.

\section{PATIENT 3}

H.M., a 40-year-old man, presented in 1950 with recurrent biliary colic and jaundice. Cholecystectomy and exploration of the common bile duct were performed. Achlorhydria was then demonstrated and a gastric biopsy showed atrophic gastritis with intestinal metaplasia. Intermittent indigestion continued. Between 1950 and 1960 a further five gastric biopsies showed similar changes. In 1962 the Schilling test gave a normal result and from 1959 to 1964 serum vitamin $B_{12}$ estimations gave normal results. Tests for gastric autoantibodies were negative. In 1966, a barium meal examination $x$-ray was done because of persistent indigestion. There was thought to be a small lesser curve ulcer but this was not reviewed and the patient improved. In 1968, another barium meal $x$-ray examination was performed because of recurrence of symptoms and revealed a polypoid carcinoma of the body of the stomach. A Polya gastrectomy was performed. The patient has remained well with no evidence of recurrence of the tumour.

\section{PATIENT 4}

J.S., a 57-year-old woman, presented in 1949 with a seven-year history of indigestion. Radiological examinations of the stomach and gallbladder were normal. Gastroscopy revealed an atrophic mucosa. Several gastric biopsies revealed chronic atrophic gastritis (Fig. 2). In 1951 achlorhydria was demonstrated. From 1951 to 1965 several further gastric biopsies showed unchanged appearances. Between 1959 and 1961 the absorption of vitamin $B_{12}$ was normal on four occasions, but in 1962 a Schilling test result of $5.4 \%$ together with low serum vitamin $B_{12}$ of $100 \mathrm{pg} / \mathrm{ml}$, led to treatment with vitamin $B_{12}$ even though there were no haematological or neurological signs of vitamin $B_{12}$ deficiency. This was stopped nine months later. A further Schilling test in 1970 gave a normal result. In 1965 and 1970 tests for gastric autoantibodies were negative. In 1965, a 


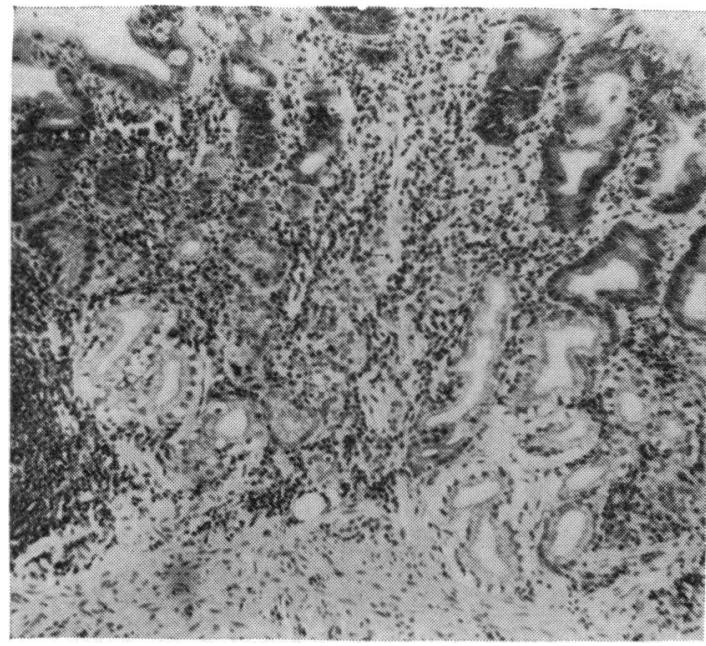

Fig. 2 Gastric biopsy obtained from patient J.S. in 1949. Marked atrophic gastritis. $(H$ and $E, \times 100$.)

second barium meal $x$-ray examination was normal. In 1970, because of exacerbation of indigestion, a barium meal $x$-ray examination and gastroscopy were done and revealed a constricting carcinoma of the body of the stomach (Fig. 3). Laparotomy revealed peritoneal and hepatic metastases. A Polya gastrectomy was performed but the patient died four months later. The resected stomach showed an ulcerated tumour infiltrating the body and proximal antrum.

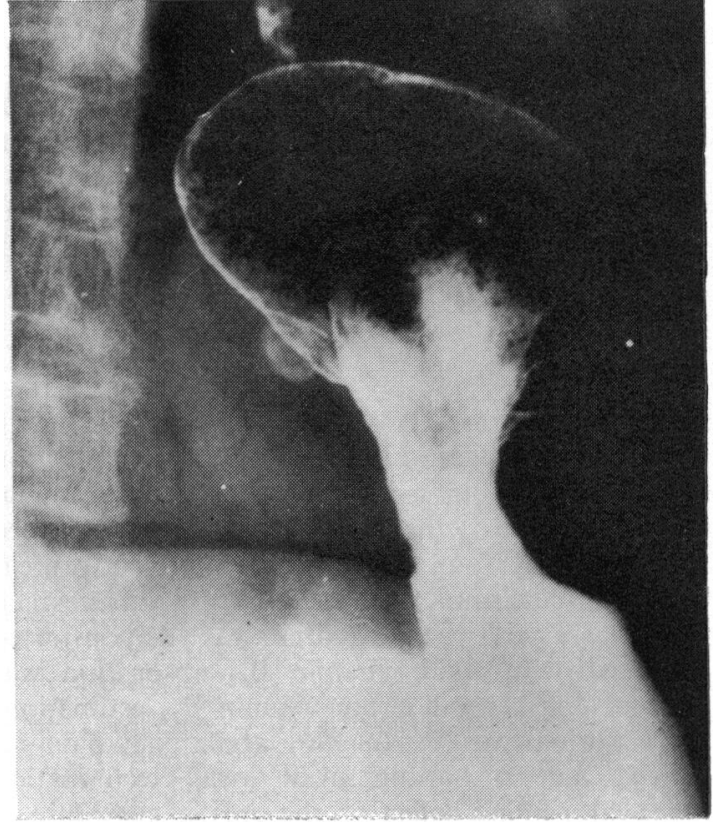

Fig. 3 Barium meal in patient J.S. in 1970. Irregular constriction in body of stomach indicating carcinoma. (The barium meal in 1965 was normal.)

\section{SUMMARY OF CASES}

The details of the four cases are summarized in the Table. Gastric carcinoma was detected nine, 10, 18,

\begin{tabular}{|c|c|c|c|c|c|c|c|c|c|c|c|c|}
\hline \multirow{2}{*}{$\begin{array}{l}\text { Patient } \\
\text { (sex and } \\
\text { age) }\end{array}$} & \multirow[t]{2}{*}{$\begin{array}{l}\text { Barium } \\
\text { Meal }\end{array}$} & \multirow[t]{2}{*}{$\begin{array}{l}\text { Gastro- } \\
\text { scopy }\end{array}$} & \multirow{2}{*}{$\begin{array}{l}\text { Gastric } \\
\text { Biopsies } \\
\text { (no. and } \\
\text { date) }\end{array}$} & \multirow{2}{*}{$\begin{array}{l}\text { Acid } \\
\text { Secretion } \\
\text { (no. of tests) }\end{array}$} & \multirow{2}{*}{$\begin{array}{l}\text { Vitamin } B_{12} \\
\text { Absorption } \\
(\%)\end{array}$} & \multirow[t]{2}{*}{$\begin{array}{l}\text { Serum } B_{12} \\
(p g / m l)\end{array}$} & \multirow{2}{*}{$\begin{array}{l}\text { Parietal } \\
\text { Cell } \\
\text { Antibody }\end{array}$} & \multirow{2}{*}{$\begin{array}{l}\text { Intrinsic } \\
\text { Factor } \\
\text { Antibody }\end{array}$} & \multirow{2}{*}{$\begin{array}{l}\text { Site and } \\
\text { Type of } \\
\text { Carcinoma }\end{array}$} & \multicolumn{3}{|c|}{$\begin{array}{l}\text { Histological Features from } \\
\text { Gastrectomy Specimen }\end{array}$} \\
\hline & & & & & & & & & & $\begin{array}{l}\text { Body } \\
\text { Mucosa }\end{array}$ & $\begin{array}{l}\text { Antral } \\
\text { Mucosa }\end{array}$ & $\begin{array}{l}\text { Intestinal } \\
\text { Metaplast }\end{array}$ \\
\hline $\begin{array}{l}\text { G.T. } \\
\text { (M 54) }\end{array}$ & $\begin{array}{l}\mathrm{N}, 1947 \\
\mathrm{Ca}, 1961\end{array}$ & $\mathrm{Ca}, 1961$ & $\begin{array}{l}6(1951-60) \\
A G\end{array}$ & $\begin{array}{l}5(1947-61) \\
\text { Achlorhydria }\end{array}$ & $57 \cdot 3^{1}, 1960$ & 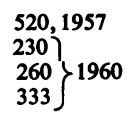 & NT & $\mathbf{N T}$ & $\begin{array}{l}\text { Body, ul- } \\
\text { cerating } \\
\text { anaplastic } \\
\text { adeno- } \\
\text { carcinoma }\end{array}$ & $\begin{array}{l}\text { Multifocal } \\
\text { atrophic } \\
\text { gastritis }\end{array}$ & $\begin{array}{l}\text { Diffuse } \\
\text { atrophic } \\
\text { gastritis }\end{array}$ & Focal \\
\hline $\begin{array}{l}\text { L.M. } \\
\text { (F 64) }\end{array}$ & $\begin{array}{l}\mathrm{N}, 1946 \\
\mathrm{~N}, 1951 \\
\mathrm{Ca}, 1960\end{array}$ & AG, 1951 & $\begin{array}{l}6(1951-60) \\
A G\end{array}$ & $\begin{array}{l}5(1946-60) \\
\text { Achlorhydria }\end{array}$ & NT & $\begin{array}{l}\left.\begin{array}{l}328 \\
290 \\
303\end{array}\right\} 1959 \\
250,1960\end{array}$ & NT & NT & $\begin{array}{l}\text { Body, liniti } \\
\text { plastica, } \\
\text { adeno- } \\
\text { carcinoma }\end{array}$ & $\begin{array}{l}\text { is Multi- } \\
\text { focal } \\
\text { atrophic } \\
\text { gastritis }\end{array}$ & Normal & Absent \\
\hline $\begin{array}{l}\text { H.M. } \\
\text { (M 40) }\end{array}$ & $\begin{array}{l}\text { ? GU } 1966 \\
\text { Ca, } 1968\end{array}$ & - & $\begin{array}{l}6(1950-60) \\
A G\end{array}$ & $\begin{array}{l}2(1950-60) \\
\text { Achlorhydria }\end{array}$ & $15^{2}, 1962$ & $\begin{array}{l}303,1959 \\
290,1960 \\
220,1962 \\
550,1964\end{array}$ & $\begin{array}{c}\text { Negative, } \\
1964 \\
\text { Negative, } \\
1969\end{array}$ & $\begin{array}{c}\text { Negative, } \\
1964 \\
\text { Negative, } \\
1969\end{array}$ & $\begin{array}{l}\text { Body, } \\
\text { polypoid } \\
\text { mucinous } \\
\text { adeno- } \\
\text { carcinoma }\end{array}$ & $\begin{array}{l}\text { Multifocal } \\
\text { atrophic } \\
\text { gastritis }\end{array}$ & $\begin{array}{l}\text { Diffuse } \\
\text { atrophic } \\
\text { gastritis }\end{array}$ & Focal \\
\hline $\begin{array}{l}\text { J.S. } \\
\text { (F 57) }\end{array}$ & $\begin{array}{l}\mathbf{N}, 1949 \\
\mathbf{N}, 1965 \\
\mathrm{Ca}, 1970\end{array}$ & $\begin{array}{l}\mathrm{AG}, 1949 \\
\mathrm{Ca}, 1970\end{array}$ & $\begin{array}{l}16(1949-70) \\
A G\end{array}$ & $\begin{array}{l}\text { 2(1951-59) } \\
\text { Achlorhydria }\end{array}$ & $\begin{array}{c}49^{1} \\
83 \\
14,^{2} 1961 \\
5,295 \\
5,^{2} 1962 \\
10 \cdot 6,^{2} 1970\end{array}$ & $\begin{array}{l}\left.\begin{array}{l}300,1957 \\
100 \\
107\end{array}\right\} 1959 \\
1280,1970\end{array}$ & $\begin{array}{c}\text { Negative, } \\
1965 \\
\text { Negative, } \\
1970\end{array}$ & $\begin{array}{c}\text { Negative, } \\
1965 \\
\text { Negative, } \\
1970\end{array}$ & $\begin{array}{l}\text { Body, } \\
\text { ulcerating } \\
\text { anaplastic } \\
\text { adeno- } \\
\text { carcinoma }\end{array}$ & $\begin{array}{l}\text { Multifocal } \\
\text { atrophic } \\
\text { gastritis }\end{array}$ & $\begin{array}{l}\text { Diffuse } \\
\text { atrophic } \\
\text { gastritis }\end{array}$ & $\begin{array}{l}\text { Focal } \\
\text { (absent } \\
\text { close to } \\
\text { carcinom }\end{array}$ \\
\hline
\end{tabular}

Table Clinical and pathological details of four patients with atrophic gastritis developing gastric carcinoma $\mathbf{N T}=$ not tested $; \mathbf{N}=$ normal $; \mathbf{C a}=$ carcinoma $\mathbf{G U}=$ gastriculcer $\mathbf{A G}=$ atrophic gastritis ' Faecal excretion (normal $30-90 \%$ absorption)

s Schilling test (normal $>10 \%$ excretion) 
and 21 years after the diagnosis by gastric biopsy of atrophic gastritis. Three of the four patients had barium meal $x$-ray examinations at presentation and two of these also had a gastroscopy, and gastric carcinoma was not evident; in the other patient 18 years elapsed before carcinoma was detected. These four patients all presented with indigestion. Two of the patients were not tested for circulating gastric autoantibodies, both having died before such tests were available; the other two gave negative results to tests for both parietal cell and intrinsic factor antibodies. Serum vitamin $B_{12}$ levels were estimated in all patients and were normal on several occasions in three; they were decreased in the fourth patient who, however, had only a transiently abnormal vitamin $\mathrm{B}_{12}$ absorption. Three of the patients were blood group A and the fourth (G.T.) was group B.

\section{HISTOLOGICAL EXAMINATION OF OPERATIVE} SPECIMENS

Sections taken from the gastric mucosa distant from the site of the cancer revealed diffuse chronic inflammation in all four specimens. However, glandular atrophy was focal and patchy, and areas containing many acid- and pepsin-secreting cells could be found in sections of the body mucosa from the four patients (Fig. 4). Intestinal metaplasia was present in three of the four specimens; this change was also focal and in one patient (J.S.) it was absent for a distance of two low-power microscopic fields in the mucosa surrounding the carcinoma (Fig. 5).

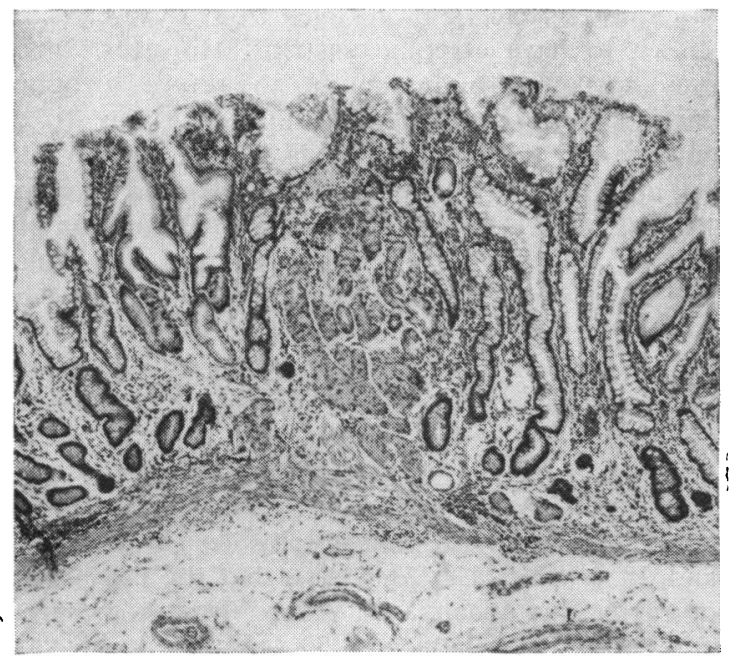

Fig. 4 Section of body mucosa from gastrectomy specimen in patient G.T. shows multifocal atrophic gastritis. Note the area of normal gastric glands in the centre of the section. ( $H$ and $E, \times 40$.)

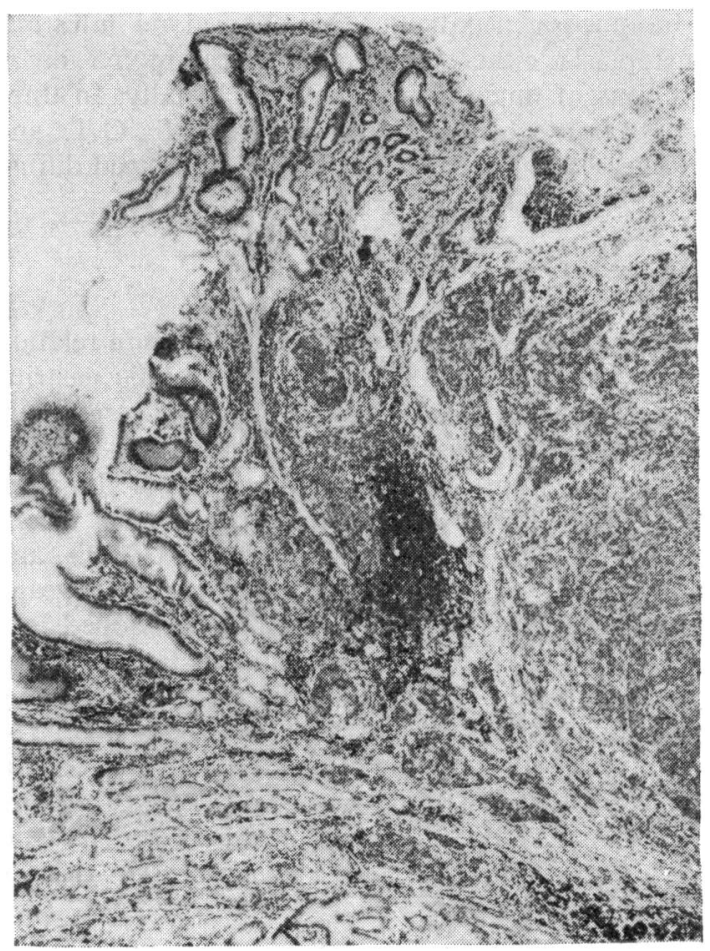

Fig. 5 Edge of carcinoma in patient J.S. shows multifocal gastritis without intestinal metaplasia over several low-power fields adjacent to the tumour. ( $H$ and $E, \times 40$.)

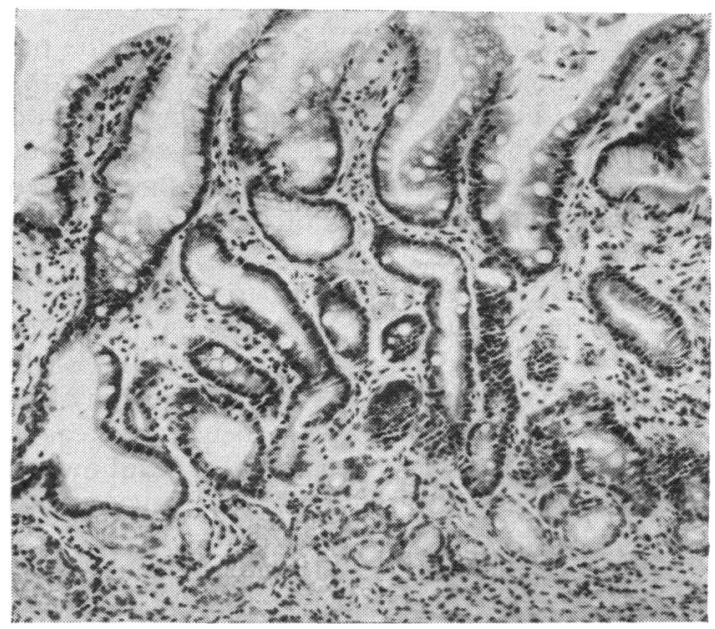

Fig. 6 Section of antral mucosa from gastrectomy specimen in patient G.T. shows subtotal atrophy of antral glands and intestinal metaplasia. ( $H$ and $E, \times 100$.) 
The mucosa in patient L.M. showed no intestinal metaplasia either overlying the carcinoma or in sections of mucosa proximally or distally. In three of the four specimens (from patients J.S., G.T., and H.M.) sections of the antral mucosa showed diffuse atrophy with intestinal metaplasia (Fig. 6).

\section{Discussion}

The four cases described are remarkable in relation to the long period during which atrophic gastritis was demonstrable before the detection of carcinoma. Long-term surveys of cases of atrophic gastritis proven at biopsy are few. Fairley et al (1955) from this Unit found no gastric carcinomas in 32 patients over a five-year survey. Siurala, Varis, and Wiljasalo (1966), in a survey covering 10-15 years, found that nine gastric carcinomas developed in a group of 116 patients with atrophic gastritis, whereas no carcinomas developed in groups with normal gastric mucosa or with superficial gastritis. The occurrence of carcinoma of the stomach in four of our 40 patients with atrophic gastritis followed for up to 22 years is comparable, and indicates that patients with this condition incur a substantial risk of developing malignancy.

The four patients presented here were considered to have 'simple' atrophic gastritis for the following reasons. First, vitamin $B_{12}$ absorption was normal in the three patients tested, and vitamin $B_{12}$ deficiency did not develop over a 14-year period of observation in the fourth patient. Second, in the two patients so tested, gastric autoantibodies were not detected. The patients already mentioned described by Siurala et al (1966) were not screened for the presence of gastric autoantibodies and it is possible that their series included patients with latent pernicious anaemia, in that 21 of 103 patients tested had decreased vitamin $\mathbf{B}_{12}$ absorption. Third, the pattern of the gastritis was of the multifocal type in all four patients; the mucosal changes in simple atrophic gastritis not associated with gastric autoantibodies are usually multifocal in distribution (te Velde, Hoedemaeker, Anders, and Nieweg, 1966). Fourth, the antral mucosa was found to be severely involved by gastritis in three of the patients, whereas in patients with pernicious anaemia the antral mucosa is spared and only the body and fundic mucosa show diffuse atrophy (Magnus and Ungley, 1938).

Kaplan and Rigler (1945) reported a $12 \%$ incidence of gastric carcinoma in fully developed pernicious anaemia. Shearman, Finlayson, Wilson, and Samson (1966), however, suggested that the extent of this association had been underestimated. If pernicious anaemia significantly contributed to the overall prevalence of carcinoma of the stomach then a higher than normal incidence of parietal cell and intrinsic factor antibodies could be expected in carcinoma of the stomach. However, the findings of Ungar, Strickland, and Francis (1971) indicate that this is not the case. In fact Kravetz, van Noorden, and Spiro (1967) found that only $8 \%$ of 38 patients with gastric carcinoma showed parietal cell antibody even though $80 \%$ of these patients had advanced gastritis. These observations indicate that the predisposition to carcinoma of the stomach is based on chronic gastritis per se and not particularly on gastritis with autoimmune features. Indeed, if simple atrophic gastritis, were shown to be more likely to predispose to gastric carcinoma than autoimmune gastritis, then the presence of parietal cell antibody would take on a new significance.

It has been suggested that carcinoma of the stomach arising in patients with pernicious anaemia may originate in areas of intestinal metaplasia (Siurala, Eramaa, and Tapiovaara, 1959). The evidence from the present case studies indicates that this may not be true for carcinoma arising from simple atrophic gastritis, as in one patient intestinal metaplasia was not observed in multiple sections from all areas of the resected stomach, and in a further patient the mucosa immediately surrounding the carcinoma was free from this change.

The suggested linking of atrophic gastritis with gastric carcinoma must take into account the frequency of gastritis in the normal population. Biopsy study of a normal population has been performed in a Finnish commune (Siurala, Isokoski, Varis, and Kekki, 1968), with the result that $28 \%$ of 142 randomly selected subjects aged from 15 to 65 were shown to have atrophic gastritis. However, when only instances of moderate to severe atrophic gastritis are considered the incidence was $10 \%$, and one-third of these subjects had circulating parietal cell antibody (Isokoski, Krohn, Varis, and Siurala, 1969). Comparable figures for an unselected sample of the Australian population are not available. The $28 \%$ incidence of severe atrophic gastritis in 1,000 consecutive gastric biopsies reported from this Unit by Joske, Finckh, and Wood (1955) gives some indication of its prevalence in Australia, although most of these patients had gastrointestinal diseases.

If it be accepted, that-for an adult populationthe prevalence of atrophic gastritis lies between $10 \%$ and $28 \%$ (Siurala et al, 1968), that the prevalence of pernicious anaemia as judged from a hospital population over the age of 50 years is $1 \%$ (Ungar, 1968), and that there is an incidence of gastric carcinoma of $10 \%$ in both, then for every case of gastric carcinoma supervening on pernicious anaemia there will be some 10-28 cases supervening in 
atrophic gastritis without pernicious anaemia. It is unknown what determines the actual occurrence of gastric carcinoma in certain subjects with either form of atrophic gastritis. What can be said is that atrophic gastritis without pernicious anaemia is a numerically more important precursor of gastric carcinoma than is the atrophic gastritis which is associated with pernicious anaemia.

The authors wish to thank Drs I. J. Wood and D. C. Cowling for their early documentation of the patients described in this study and Dr P. S. Bhathal for reviewing the pathological specimens and providing the photomicrographs.

Requests for reprints should be addressed to Dr R. G. Strickland, Clinical Research Unit, Walter and Eliza Hall Institute of Medical Research, P.O., Royal Melbourne Hospital, Victoria, 3050, Australia.

This study was supported by grants from the National Health and Medical Research Council of Australia (R.G.S., I.R.M.).

\section{References}

Anderson, B. B. (1964). Investigations into the Euglena method for the assay of the vitamin $B_{12}$ in serum. J. clin. Path., 17, 14-26.

Fairley K. F., Turner, C. N., Mackay, M. A., and Joske, R. A. (1955). Atrophic gastritis: a five-year survey of thirty-two cases proven by gastric biopsy. Med.J. Aust., 2, 1085-1088.

Gottlieb, C., Lau, K.-S., Wasserman, L. R., and Herbert, V. (1965) Rapid charcoal assay for intrinsic factor (IF), gastric juice unsaturated $B_{12}$ binding capacity, antibody to IF and serum unsaturated $B_{1}$, binding capacity. Blood, 25, 875-884.

Heinle, R. W., Welch, A. D., Scharf, V., Meacham, G. C., and Prusoff, W. H. (1952). Studies of excretion and absorption of $\mathrm{Co}^{\circ 0}$-labeled vitamin $\mathrm{B}_{12}$ in pernicious anaemia. Trans. Ass. Amer. Phycns, 65, 214-222.

Hutner, S. H., Bach, M. K., and Ross, G. I. M. (1956). A sugar containing basal redium for vitamin $B_{12}$ assay with Euglena: application to body fluids. J. Protozool., 3, 101-112

Imai, T., Kubo, T., and Watanabe, H. (1971). Chronic gastritis in Japanese with reference to high incidence of gastric carcinoma. J. nat. Cancer Inst., 47, 179-195.

Isokoski, M., Krohn, K., Varis, K., and Siurala, M. (1969). Parietal cell and intrinsic factor antibodies in a Finnish rural population sample. Scand. J. Gastroent., 4, 521-527.

Joske, R. A., Finckh, E. S., and Wood, I. J. (1955). Gastric biopsyA study of 1000 consecutive successful gastric biopsies. Quart. J. Med., 24, 269-294.

Kaplan, H. S., and Rigler, L. G. (1945). Pernicious anaemia and carcinoma of the stomach. Amer. J. med. Sci., 209, 339-348.

Kay, A. W. (1953). Effect of large doses of histamine on gastric secretion of $\mathrm{HCl}$ : an augmented histamine test. Brit. med. J., 2, 77-80.

Kravetz, R. E., Van Noorden, S., and Spiro, H. M. (1967). Parietalcell antibodies in patients with duodenal ulcer and gastric cancer. Lancet, 1, 235-237.
Magnus, H. A. (1958). A re-assessment of the gastric lesion in pernicious anaemia. J. clin. Path., 11, 289-295.

Magnus, H. A., and Ungley, C. C. (1938). The gastric lesion in pernicious anaemia. Lancet, $1,420-421$.

Morson, B. C. (1955a). Carcinoma arising from areas of intestinal metaplasia in the gastric mucosa. Brit. J. Cancer, 9, 377-385.

Morson, B. C. (1955b). Intestinal metaplasia of the gastric mucosa. Brit. J. Cancer, 9, 365-376.

Ross, G. I. M. (1952). Vitamin $B_{12}$ assay in body fluids using Euglena gracilis. J. clin. Path., 5, 250-256.

Schilling, R. F. (1953). Intrinsic factor studies II: The effect of gastric juice on the urinary exeretion of radioactivity after the oral administration of radioactive vitamin $\mathbf{B}_{12}$. J. Lab. clin. Med., 42, 860-866.

Shearman, D. J. C., Finlayson, N. D. C., Wilson, R., and Samson, R. R. (1966). Carcinoma of the stomach and early pernicious anaemia. Lancet, 2, 403-405.

Siurala, M., Erămaa, E., and Tapiovaara, J. (1959). Pernicious anemia and gastric carcinoma. Acta med. scand., 164, 431-436.

Siurala, M., Isokoski, M., Varis, K., and Kekki, M. (1968). Prevalence of gastritis in a rural population. Scand. J. Gastroent., 3,211-223.

Siurala, M., Varis, K., and Wiljasalo, M. (1966). Studies of patients with atrophic gastritis: A ten to fifteen year follow-up. Scand. J. Gastroent., 1, 40-48.

Te Velde, K., Hoedemaeker, P. J., Anders, G. J. P. A., Arends, A., and Nieweg, H. O. (1966). A comparative morphological and functional study of gastritis with and without autoantibodies. Gastroenterology, 51, 138-148.

Ungar, B. (1967). Detection and titration of antibody to intrinsic factor by a modified charcoal method. Aust. J. exp. Biol. med. Sci., 45, 317-321.

Ungar, B. (1968). Antibody to gastric intrinsic factor in blood donors and hospital patients. Aust. Ann. Med., 17, 107-109.

Ungar, B., Stocks, A. E., Martin, F. I. R., Whittingham, S., and Mackay, I. R. (1968). Intrinsic-factor antibody, parietal-cell antibody and latent pernicious anaemia in diabetes mellitus. Lancet, 2, 415-418.

Ungar, B., Strickland, R. G., and Francis, C. M. (1971). The prevalence and significance of circulating antibodies to gastric intrinsic factor and parietal cells in gastric carcinoma. Gut, 12, 903-905.

Weiden, S. (1949). Some observations on the secretion of the stomach with special reference to mucus. Med. J. Aust., 2, 81-83.

Whittingham, S., and Mackay, I. R. (1969). Laboratory methods for diagnosis of autoimmune disease. Med. J. Aust., 1, 1200-1205.

Wood, I. J., Cowling, D. C., Ungar, B., and Gray, A. (1960). Serum vitamin $B_{12}$ levels in chronic atrophic gastritis. Aust. Ann. Med., 9, 309-317.

Wood, I. J., Doig, R. K., Motteram, R., and Hughes, A. (1949). Report on 55 biopsies using a new flexible gastric biopsy tube. Lancet, 1, 18-21.

Wood, I. J., Ralston, M., Ungar, B., and Cowling, D. C. (1964). Vitamin $B_{1}$, deficiency in chronic gastritis. Gut, 5, 27-37.

\section{Addendum}

In a recent report (Imai, Kubo, and Watanabe, 1971), in which chronic gastritis with antral involvement and gastric cancer in Americans and Japanese were compared, it appeared that chronic gastritis could determine the much higher prevalence of gastric cancer in Japanese. 